\title{
Drug Allergy Clinical Characteristics in Pediatrics
}

\author{
R. Devina Fathia Almira, ${ }^{1}$ Gartika Sapartini ${ }^{2}$ Vycke Yunivita Kusumah Dewi ${ }^{3}$ \\ ${ }^{1}$ Faculty of Medicine Universitas Padjadjaran, ${ }^{2}$ Department of Child Health Faculty of Medicine, \\ Universitas Padjadjaran/Dr. Hasan Sadikin General Hospital Bandung, ${ }^{3}$ Department of \\ Pharmacology and Therapy Faculty of Medicine Universitas Padjadjaran
}

\begin{abstract}
Background: A drug allergy causes a morbidity and a mortality due to its various range of clinical manifestation. Unfortunately, a study focusing in pediatric drug allergy is insufficient, especially in Bandung. Thus, this study is conducted to determine the clinical characteristic of pediatric drug allergy in Dr. Hasan Sadikin General Hospital Bandung.

Methods: This study was a retrospective descriptive study using medical records of pediatric drug allergy patients between 2010-2015 in Dr. Hasan Sadikin General Hospital Bandung taken with total sampling method. The variables were patient age, gender, causative drug, and clinical manifestation. Clinical manifestation was then divided into exanthem, urticaria, erythema multiforme, Steven-Johnson's syndrome/ toxic epidemiolytic necrosis (SJS/TEN), and fixed drug eruption (FDE).

Results: Out of 101 patients, only 71 were included in the study due to incomplete medical records of the rest. There were 34 (47.89\%) males and 37 (52.11\%) females. Patients' age ranged from 1-18 years old with the mean of 7.4 years old. The most common clinical manifestation was SJS/TEN with 25 (35.21\%) patients, followed by exanthem with $22(30.98 \%)$ patients. The most common suspected causative drug was non-steriodal anti inflammatory drugs (NSAID) (24\%), followed with penicillin (21\%).

Conclusions: Most common manifestation of pediatric drug allergy in female is SJS/TEN, meanwhile in male is exanthema. Steven-Johnson's syndrome/toxic epidemiolytic necrosis mostly occurs at the age group of 12-18 years old, and exanthema at the age group of 0-3 years old. This condition is mostly caused by NSAID and penicillin.
\end{abstract}

Keywords: Clinical manifestation, drug allergy, pediatric

\section{Introduction}

Drug allergy is difficult to diagnose most of the time due to the wide variability of symptoms. The diagnosis require a detailed history taking and patient examination to distinguish it from other diseases with the similiar outcome and this often costs in patient's morbidity or even mortality. ${ }^{1}$ Drug allergy accounts for 3-6\% of patient's admission to hospital and occurs in $10-15 \%$ hospitalized patients. ${ }^{1}$ Clinical manifestation of drug allergy can be diverse, from skin rashes such as maculopapular and urticaria, to severe manifestation such as Steven-Johnson's syndrome/toxic epidermal necrolytic (SJS/TEN) which may cause a death. $^{2}$

In Indonesia, especially Bandung, Jawa Barat, there is an insufficient data of pediatric drug allergy. This study aims to determine the characteristic of pediatric drug allergy that occured in Dr. Hasan Sadikin General Hospital
Bandung.

\section{Methods}

This study is a retrospective descriptive study carried out in Dr. Hasan Sadikin General Hospital Bandung using medical record of pediatrics patients between 2010 to 2015 . This study was approved by the Health Research Ethic Committee of Dr. Hasan Sadikin General Hospital Bandung. The population of medical records in pediatrics patients with drug allergy diagnosed between January 2010 to September 2015. Total sampling method taken and Total of 101 medical records were collected.

The inclusion criteria completed the medical records of pediatrics inpatients and outpatients aged 1-18 years old were diagnosed with drug allergy between January 2010 until September 2015. The exclusion criteria included those with congenital

Correspondence: R. Devina Fathia Almira, Faculty of Medicine, Universitas Padjadjaran, Jalan Raya Bandung-Sumedang Km.21, Jatinangor, Sumedang, Indonesia, Phone: +6281221112525 Email: devinafathia@gmail.com 
Table 1 Distribution of Gender on Clinical Manifestation

\begin{tabular}{lcc}
\hline \multirow{2}{*}{ Clinical Manifestation (n=71) } & \multicolumn{2}{c}{ Gender (n (\%)) } \\
\cline { 2 - 3 } & Female (n=37) & Male (n=34) \\
\hline SJS/TEN & $16(43.2 \%)$ & $9(26.4 \%)$ \\
Exanthem & $8(21.6 \%)$ & $14(41.2 \%)$ \\
Urticaria & $6(16.2 \%)$ & $4(11.4 \%)$ \\
Erythema Multiforme & $6(16.2 \%)$ & $5(14.7 \%)$ \\
FDE & $1(2.7 \%)$ & $2(5.8 \%)$ \\
\hline
\end{tabular}

anomaly or comorbidities that could affect the outcome of drug allergy such as known skin or other immunology disease.

The data collected in this study consisted of patient gender, clinical manifestation of pediatric drug allergy, and suspected causative drug which used a categorical measurement scale, also a patient age which used a numerical measurement scale. Variables were then analyzed using Microsoft excel software.

\section{Results}

The total subjects were 101 patients, 85 inpatients and 16 outpatients, however patients who met the inclusion criteria were 61 inpatients and 10 outpatients, giving a total of 71 pediatrics patients diagnosed with drug allergy between 2010-2015. Other medical records were excluded due to the incomplete of medical records

Pediatric patients for drug allergy were 34 (47.89\%) in males and 37 (52.11\%) in females. The patiens't age were ranged from 1 to 18 years old with the mean age of 7.4 years old. Distribution of patient gender on clinical manifestation were shown (Table 1).

Patients in the age group of 12-18 years old have the highest number of SJS/TEN, meanwhile age group of $0-3$ years old has the highest number of exanthem as clinical manifestation (Table 2). > 1 year.

Suspected causative drug showed no specific distribution on age of patients. However, NSAID showed to be found most on

Table 2 Distribution of Age on Clinical Manifestation and Suspected Causative Drug

\begin{tabular}{|c|c|c|c|c|}
\hline & \multicolumn{4}{|c|}{ Age (n (\%)) } \\
\hline & $\begin{array}{c}0-3 \text { years } \\
(n=21)\end{array}$ & $\begin{array}{c}\text { 4-6 years } \\
(n=12)\end{array}$ & $\begin{array}{c}7-11 \text { years } \\
(n=18)\end{array}$ & $\begin{array}{c}12-18 \text { years } \\
(n=20)\end{array}$ \\
\hline \multicolumn{5}{|c|}{ Clinical Manifestation ( $\mathrm{n}=71)$} \\
\hline SJS/TEN & $4(19.1)$ & $4(33.3)$ & $7(38.9)$ & $10(50.0)$ \\
\hline Exanthem & $9(42.8)$ & $2(16.7)$ & $5(17.8)$ & $6(30.0)$ \\
\hline Urticaria & $5(23.8)$ & 0 & $4(22.2)$ & $1(5.0)$ \\
\hline Erythema Multiforme & $3(14.2)$ & $4(33.3)$ & $2(11.1)$ & $2(10.0)$ \\
\hline FDE & 0 & $2(16.7)$ & 0 & $1(5.0)$ \\
\hline \multicolumn{5}{|c|}{ Suspected Causative Drug $(n=71)$} \\
\hline NSAID & $4(19.1)$ & $5(41.7)$ & $5(17.8)$ & $3(15.0)$ \\
\hline Penicillin & $5(23.8)$ & $2(16.7)$ & $4(22.2)$ & $4(20.0)$ \\
\hline Cotrimoxazole & $1(4.7)$ & $1(8.3)$ & $2(11.1)$ & $3(15.0)$ \\
\hline TB Drugs & $1(4.7)$ & 0 & $2(11.1)$ & $2(10.0)$ \\
\hline Cephalosporin & $3(14.2)$ & $1(8.3)$ & $1(5.6)$ & $4(20.0)$ \\
\hline Chloramphenicol & $1(4.7)$ & $1(8.3)$ & $3(16.7)$ & $1(5.0)$ \\
\hline Benzodiazepine & $1(4.7)$ & 0 & $1(5.6)$ & $2(10.0)$ \\
\hline Others & $5(23.8)$ & $2(16.7)$ & 0 & $1(5.0)$ \\
\hline
\end{tabular}




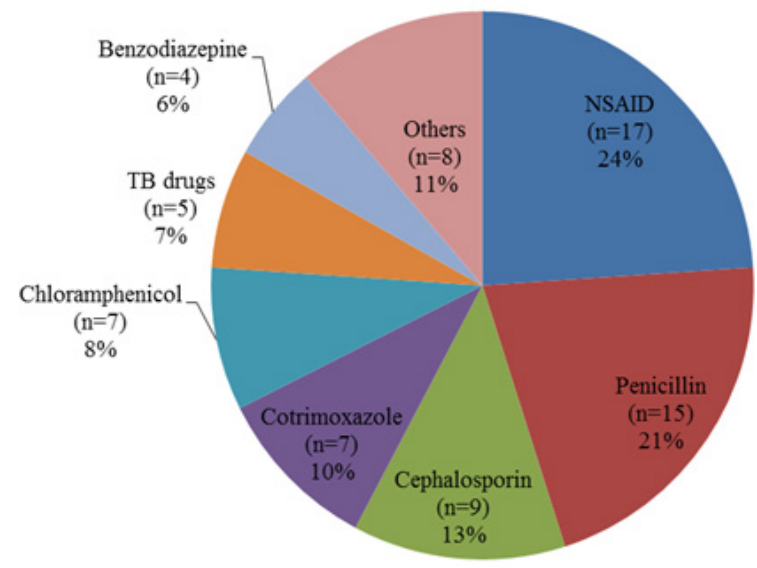

Figure Suspected Causative Drug Distribution

the age group of 4-6 years old and penicillin on the age group of $0-3$ years old(Table 2 ).

Non-steriodal anti inflammatory drugs (NSAID) was found to be the most common suspected drug in causing drug allergy in pediatrics. The percentage of NSAID and other drugs can be seen in the Figure.

The most common suspected causative drug was NSAID with 17 patients which consist of paracetamol in 12 patients, ibuprofen in 3 patients, diclofenac in 1 patient, and meloxicam in 1 patient. The second most common suspected causative drug was penicillin with 15 patients, consist of ampicillin in 10 patients and amoxicillin in 5 patients. The third was cephalosporin with 9 patients, consist of cefotaxime in 5 patients, cefixime in 3 patients, and ceftriaxone in 1 patient.

Other drugs found in this study were cotrimoxazole with 6 patients, antituberculosis drugs with 5 patients, benzodiazepine (diazepam) with 4 patients.
Other drugs included immunos with 2 patients, nevirapine with 2 patients, fradiomycine with 1 patient, leunase with 1 patient, propolis with 1 patient, and vostrin with 1 patient.

This study is also attempted to determine the distribution of the suspected causative drug on patients clinical manifestation (Table 3).

This study is also attempted to determine which suspected causative drug made the drug allergy reaction after the administration of that single drug only, and which did so after the administration with other drugs (Table 4).

\section{Discussion}

This study reveals that from a total of 71 patients, 34 (47.89\%) are male and 37 (52.11\%) are female. Patients age are ranged from 1-18 old with the mean of 7.4 years old. This finding corresponds with a study that

Table 3 Distribution of Suspected Causative Drug on Clinical Manifestation

\begin{tabular}{|c|c|c|c|c|c|c|c|c|}
\hline \multirow{3}{*}{$\begin{array}{c}\text { Clinical } \\
\text { Manifestation } \\
(n=71)\end{array}$} & \multicolumn{8}{|c|}{ Suspected Causative Drug (n (\%)) } \\
\hline & \multicolumn{4}{|l|}{$\begin{array}{l}\text { Sympto } \\
\text { matic }\end{array}$} & \multicolumn{4}{|l|}{ Causative } \\
\hline & $\begin{array}{l}\text { NSAID } \\
(n=17)\end{array}$ & $\begin{array}{c}\text { Penicillin } \\
(n=15)\end{array}$ & $\begin{array}{c}\text { Cotrimoxa } \\
\text { zole } \\
(n=7)\end{array}$ & $\begin{array}{c}\text { TB } \\
\text { Drugs } \\
(n=5)\end{array}$ & $\begin{array}{c}\text { Cephalos } \\
\text { porin } \\
(n=9)\end{array}$ & $\begin{array}{c}\text { Chloram } \\
\text { phenicol } \\
(n=6)\end{array}$ & $\begin{array}{c}\text { Benzo } \\
\text { diazepine } \\
(n=4)\end{array}$ & $\begin{array}{c}\text { Others } \\
(n=8)\end{array}$ \\
\hline SJS/TEN & $5(29.4)$ & $5(33.3)$ & $4(57.1)$ & $3(60.0)$ & $3(33.3)$ & $3(50.0)$ & $1(25.0)$ & $1(12.5)$ \\
\hline Exanthem & $6(35.2)$ & $3(20.0)$ & $1(14.2)$ & $1(20.0)$ & $3(33.3)$ & $3(50.0)$ & $2(50.0)$ & $3(37.5)$ \\
\hline Urticaria & $1(5.8)$ & $4(26.7)$ & $2(28.5)$ & 0 & $2(22.2)$ & 0 & 0 & $1(12.5)$ \\
\hline $\begin{array}{l}\text { Erythema } \\
\text { Multiforme }\end{array}$ & $3(17.6)$ & $3(20.0)$ & 0 & $1(20.0)$ & $1(11.1)$ & 0 & 0 & $3(37.5)$ \\
\hline FDE & 2 (11.7) & 0 & 0 & 0 & 0 & 0 & $1(25.0)$ & 0 \\
\hline
\end{tabular}


Table 4 Distribution of Suspected Causative Drug (Single or Multi Drug Usage) on Clinical Manifestation

\begin{tabular}{|c|c|c|c|c|c|c|c|c|}
\hline \multirow{3}{*}{$\begin{array}{c}\text { Clinical } \\
\text { Manifestation } \\
(n=71)\end{array}$} & \multicolumn{8}{|c|}{ Suspected Causative Drug (n (\%)) } \\
\hline & \multicolumn{2}{|c|}{$\begin{array}{l}\text { NSAID } \\
(n=17)\end{array}$} & \multicolumn{2}{|c|}{$\begin{array}{l}\text { Penicillin } \\
\text { (n=15) }\end{array}$} & \multicolumn{2}{|c|}{$\begin{array}{c}\text { Cephalosporin } \\
(n=9)\end{array}$} & \multicolumn{2}{|c|}{$\begin{array}{c}\text { Cotrimoxazole } \\
(n=7)\end{array}$} \\
\hline & $\begin{array}{c}\text { Single } \\
\text { Drug } \\
(n=12)\end{array}$ & $\begin{array}{l}\text { Multi } \\
\text { Drugs } \\
(n=5)\end{array}$ & $\begin{array}{l}\text { Single } \\
\text { Drug } \\
(n=9)\end{array}$ & $\begin{array}{l}\text { Multi } \\
\text { Drugs } \\
(\mathrm{n}=6)\end{array}$ & $\begin{array}{l}\text { Single } \\
\text { Drug } \\
(\mathrm{n}=6)\end{array}$ & $\begin{array}{l}\text { Multi } \\
\text { Drugs } \\
(\mathrm{n}=3)\end{array}$ & $\begin{array}{l}\text { Single } \\
\text { Drug } \\
(\mathrm{n}=6)\end{array}$ & $\begin{array}{l}\text { Multi } \\
\text { Drugs } \\
(n=1)\end{array}$ \\
\hline SJS/TEN & $\begin{array}{c}4 \\
(33.3)\end{array}$ & $\begin{array}{c}1 \\
(20.0)\end{array}$ & $\begin{array}{c}3 \\
(33.3)\end{array}$ & $\begin{array}{c}2 \\
(33.3)\end{array}$ & $\begin{array}{c}2 \\
(33.3)\end{array}$ & $\begin{array}{c}1 \\
(33.3)\end{array}$ & $\begin{array}{c}3 \\
(50.0)\end{array}$ & $\begin{array}{c}1 \\
(100)\end{array}$ \\
\hline Exanthem & $\begin{array}{c}4 \\
(33.3)\end{array}$ & $\begin{array}{c}2 \\
(40.0)\end{array}$ & $\begin{array}{c}1 \\
(11.1)\end{array}$ & $\begin{array}{c}2 \\
(33.3)\end{array}$ & $\begin{array}{c}2 \\
(33.3)\end{array}$ & $\begin{array}{c}1 \\
(33.3)\end{array}$ & $\begin{array}{c}1 \\
(16.7)\end{array}$ & 0 \\
\hline Urticaria & $\begin{array}{c}1 \\
(8.3)\end{array}$ & 0 & $\begin{array}{c}3 \\
(33.3)\end{array}$ & $\begin{array}{c}1 \\
(16.7)\end{array}$ & $\begin{array}{c}1 \\
(16.7)\end{array}$ & $\begin{array}{c}1 \\
(33.3)\end{array}$ & $\begin{array}{c}2 \\
(33.3)\end{array}$ & 0 \\
\hline $\begin{array}{l}\text { Erythema } \\
\text { Multiforme }\end{array}$ & $\begin{array}{c}1 \\
(8.3)\end{array}$ & $\begin{array}{c}2 \\
(40.0)\end{array}$ & $\begin{array}{c}2 \\
(22.2)\end{array}$ & $\begin{array}{c}1 \\
(16.7)\end{array}$ & $\begin{array}{c}1 \\
(16.7)\end{array}$ & 0 & 0 & 0 \\
\hline FDE & $\begin{array}{c}2 \\
(16.7)\end{array}$ & 0 & 0 & 0 & 0 & 0 & 0 & 0 \\
\hline \multicolumn{9}{|c|}{ Suspected Causative Drug (n (\%)) } \\
\hline & \multicolumn{2}{|c|}{$\begin{array}{c}\text { TB Drugs } \\
(n=5)\end{array}$} & \multicolumn{2}{|c|}{$\begin{array}{l}\text { Chloramphenicol } \\
(n=6)\end{array}$} & \multicolumn{2}{|c|}{$\begin{array}{c}\text { Benzodiaze-pine } \\
(n=4)\end{array}$} & \multicolumn{2}{|c|}{$\begin{array}{l}\text { Others } \\
(n=8)\end{array}$} \\
\hline & $\begin{array}{l}\text { Single } \\
\text { Drug } \\
(\mathrm{n}=0)\end{array}$ & $\begin{array}{l}\text { Multi } \\
\text { Drugs } \\
(n=5)\end{array}$ & $\begin{array}{l}\text { Single } \\
\text { Drug } \\
(\mathrm{n}=3)\end{array}$ & $\begin{array}{l}\text { Multi } \\
\text { Drugs } \\
(\mathrm{n}=3)\end{array}$ & $\begin{array}{c}\text { Single } \\
\text { Drug }(n=4)\end{array}$ & $\begin{array}{l}\text { Multi } \\
\text { Drugs } \\
(\mathrm{n}=0)\end{array}$ & $\begin{array}{l}\text { Single Drug } \\
\quad(\mathrm{n}=7)\end{array}$ & $\begin{array}{l}\text { Multi } \\
\text { Drugs } \\
(\mathrm{n}=1)\end{array}$ \\
\hline SJS/TEN & 0 & $\begin{array}{c}3 \\
(60.0)\end{array}$ & $\begin{array}{c}1 \\
(33.3)\end{array}$ & $\begin{array}{c}2 \\
(66.7)\end{array}$ & $\begin{array}{c}1 \\
(25.0)\end{array}$ & 0 & $\begin{array}{c}1 \\
(14.2)\end{array}$ & 0 \\
\hline Exanthem & 0 & $\begin{array}{c}1 \\
(20.0)\end{array}$ & $\begin{array}{c}2 \\
(66.7)\end{array}$ & $\begin{array}{c}1 \\
(33.3)\end{array}$ & $\begin{array}{c}2 \\
(50.0)\end{array}$ & 0 & $\begin{array}{c}3 \\
(42.8)\end{array}$ & 0 \\
\hline Urticaria & 0 & 0 & 0 & 0 & 0 & 0 & $\begin{array}{c}1 \\
(14.2)\end{array}$ & 0 \\
\hline $\begin{array}{l}\text { Erythema } \\
\text { Multiforme }\end{array}$ & 0 & $\begin{array}{c}1 \\
(20.0)\end{array}$ & 0 & 0 & 0 & 0 & $\begin{array}{c}2 \\
(28.5)\end{array}$ & $\begin{array}{c}1 \\
(100)\end{array}$ \\
\hline FDE & 0 & 0 & 0 & 0 & $\begin{array}{c}1 \\
(25.0)\end{array}$ & 0 & 0 & 0 \\
\hline
\end{tabular}

prove gender and age do not affect clinical manifestation nor the severity of the reaction.1 Several studies also stated that there has not been a proven strong connection between gender and age to drug allergy. ${ }^{3,4}$

Clinical manifestation with most patients is SJS/TEN with $25(35.21 \%)$ patients, followed by exanthem with 22 (30.98\%) patients, urticaria with 10 (14.08\%), and FDE with 3 $(4.22 \%)$ patients. This data is different from the previous studies that stated the most abundant clinical manifestation is exanthem, followed by urticaria and SJS/TEN.,3 This could be due to the fact that Dr. Hasan Sadikin General Hospital Bandung is a central referral hospital for all hospitals in West Java, Indonesia. This means that patients with less severe manifestation could have been treated in primary or secondary health care facilities.
Furthermore, several studies also revealed cutaneous manifestations such as exanthem and erythema multiforme as the most common manifestations of drug allergy, even though it could involve any organ. ${ }^{5-8}$

This study also showed that SJS/TEN followed by urticaria has the highest number in female patients, while exanthem, followed by SJS/TEN is the highest in male patients. Although there is variation in this study, other previous studies showed that there is no correlation between gender and clinical manifestation of drug allergy in pediatrics. ${ }^{3,4}$

Patients with SJS/TEN are mainly from the age group of 12-18 years old, and those with exanthema are mainly from the age group of $0-3$ years old. However, there is barely any difference in the distribution of suspected causative drug on the age groups. 
This fact is further confirmed by recent studies which showed that generally, there were no definitive proof of age and gender impact in drug allergy. ${ }^{3,4}$

Steven-Johnson's syndrome/toxic epidemiolytic necrosisand exanthema are mainly caused by the suspected drug of NSAID and penicillin. A community study in India also showed that NSAID is the major cause for SJS/ TEN and exanthema in drug allergy. ${ }^{9}$ Moreover, Noguera-Morel et al. ${ }^{10}$ also showed a similiar result in their study of pediatric drug allergy.

NSAID dan penicillin is found as the main suspected causative drug. Several studies have discovered that antibiotic and antiinflammatory is the major causative agent in drug allergy. ${ }^{3,8,9}$ Another study in Malang, Indonesia, also showed that paracetamol and penicillin are the major suspected causative drugs for drug allergy in pediatrics. ${ }^{4}$

The majority of the suspected causative drugs generates the drug allergy when it is given as a single drug, and not combined with the other drug, except for anti-tuberculosis drugs which is always given as a combination of several different antibiotics. Drug allergy that emerged after the administration of several different drug should be further investigated to see the probability of reaction in each drug to another one that affects the drug allergy.

This study has several limitations. The first limitation of this study is the usage of patients' medical records which unfortunately means not all of the patients diagnosed between 2010-2015 can be included in this study due to technical errors such as missing or incomplete medical records. The second limitation is the diagnostic method in the medical records also mainly relied to the clinical diagnostic only, without a proper supportive examination such as IgE or a skin prick test, thus the drug variable is only written as a suspected causative drug.

Furthermore, the percentage of suspected causative drugs in this study were also not a representative of the actual percentage in the community because matching the drugs with drug actual usage percentage in the community was not done. Nevertheless, this data is still useful for public to be more aware of the drug mentioned, however the public still have to be alert in drug usage regarding to the kind due to their ability to produce drug allergy. Future cohort study in the community are expected in order to find out the true prevalence of drug allergy.

In conclusion, the most common manifestation of pediatric drug allergy in female is SJS/TEN, meanwhile in male is exanthema. Steven-Johnson's syndrome/toxic epidemiolytic necrosis occurs the most at the age group of 12-18 years old, and exanthema at the age group of $0-3$ years old, although there is no clinical correlation of age and gender to the clinical manifestation. Pediatric drug allergy is mostly caused by NSAID and penicillin.

In the future, medical personnels are expected to fill medical records more compeletely, including allergic history of patient and patient's family, medication history, causative agent of allergic reaction, and also educating patient and patient's family about allergic condition, drug allergy sign and symptoms, drug allergy first aid, and to quickly take patient to the nearest or appointed medical facility to be further treated to avoid complications. Drug allergy diagnosis also will be more solid in the future if a proper supportive examination are implemented.

\section{References}

1. Thong B, Tan T. Epidemiology and risk factors for drug allergy. Br J Clin Pharmacol. 2011;71(5):684-700.

2. Khan D, Solensky R. Drug allergy. J Allergy and Clin Immunol. 2010;125(2):126-37.

3. Heinzerling L, Tomsitz D, Anliker M. Is drug allergy less prevalent than previously assumed? A 5-year analysis. Br J Dermatol. 2011;166(1):107-14

4. Barlianto W. Faktor-faktor yang mempengaruhi derajat keparahan erupsi obat pada anak. Jurnal Kedokteran Brawijaya. 2013;26(1):148-53.

5. Demoly $P$, Adkinson N, Brockow $K$, Castells M, Chiriac A, Greenberger $P$ et al. International Consensus on drug allergy. J Allergy. 2014;69(4):420-37.

6. Gruchalla R, Pirmohamed M. Antibiotic Allergy. N Engl J Med. 2006;354(6):601-9.

7. Susilawati A, Akib AAP, Satari HI. Gambaran klinis fixed drug eruption pada anak di Rumah Sakit Cipto Mangunkusumo. Sari Pediatri. 2014;15(5):269-73

8. Warrington R, Silviu-Dan F. Drug allergy. J Allergy Clin Immunol. 2011;7(Suppl 1):10-3.

9. Raksha M, Marfatia Y. Clinical study of cutaneous drug eruptions in 200 patients. Indian J Dermatol Venereol Leprol. 2008;74(1):80-2.

10. Noguera-morel L, Hernandez-martin A. Cutaneous drug reactions in the pediatrics population. Pediatr Clin NA. 2014;61(2):403-26. 